\title{
PENERAPAN MODEL GUIDED DISCOVERY LEARNING BERBASIS KEMAMPUAN PROSES UNTUK MENINGKATKAN HASIL BELAJAR MAHASISWA PADA MATAKULIAH METODE NUMERIK
}

\author{
Anita Dewi Utami \\ Jurusan Pendidikan Matematika IKIP PGRI Bojonegoro \\ e-mail: anitadewiutami55@gmail.com
}

\begin{abstract}
Abstrak
Penelitian ini mempunyai tujuan untuk meningkatkan hasil belajar mahasiswa pada mata kuliah metode numerik. Penelitian ini menerapkan model Guided Discovery Learning berbassis keterampilan proses pada maata kuliah metode numerik. Penelitian ini dilaksanakan pada mahasiswa semester 6 IKIP PGRI Bojonegoro tahun pelajaran 2015/2016. Jenis penelitian ini adalah penelitian tindakan kelas. Setiap siklus terdiri dari empat tahapan yaitu, perencanaan tindakan, pelaksanaan tindakan, observasi/ evaluasi, dan refleksi. Teknik yang digunakan untuk mengumpulkan data pada penelitian ini adalah observasi dan tes. Hasil tes prestasi belajar pada siklus I menunjukkan bahwa persentase ketuntasan belajar klasikal belum memenuhi indikator keberhasilan, sedangkan hasil tes prestasi belajar pada siklus II menunjukkan bahwa persentase ketuntasan belajar klasikal mencapai kategori baik dan memenuhi indikator keberhasilan. Karena tindakan pada siklus II ini sudah berhasil maka tidak perlu dilakukan tindakan pada siklus selanjutnya. Hal ini menunjukkan bahwa terjadi peningkatkan hasil belajar mahasiswa pada mata kuliah metode numerik melalui model Guided Discovery Learning berbasis kemampuan proses.
\end{abstract}

Kata Kunci: Guided Discovery Learning berbasis kemampuan proses, hasil belajar, dan metode numerik

\section{PENDAHULUAN}

Peranan pendidikan adalah salah satu faktor penentu produktivitas seseorang, sehingga kualitas pendidikan merupakan faktor untuk mencapai kesuksesannya. Kualitas pendidikan yang baik tidak terlepas dari peran dosen yang dituntut mampu mewujudkan hasil belajar yang maksimal bagi mahasiswanya. Proses pendidikan yang dilaksanakan oleh dosen tidak hanya membekali mahasiswanya dengan pengetahuan, melainkan juga keteladanan sikap. Hal ini telah ditegaskan dalam Undang-undang Dasar Negara Republik Indonesia Tahun 1945 pasal 31 ayat 3, pemerintah mengusahakan satu sistem pendidikan Nasional yang meningkatkan keimanan dan ketaqwaan serta akhlak mulia dalam rangka mencerdaskan kehidupan bangsa yang diatur dalam Undang-undang. 
Berdasarkan hasil belajar mata kuliah metode numerik pada mahasiswa tahun pelajaran 2014/2015 memperoleh nilai rata-rata 65. Nilai ini masih dalam kategori cukup. Hal ini disebabkan pembelajaran masih terpusat pada dosen. Dosen mendominasi kegiatan pembelajaran sehingga mahasiswa susah untuk berkembang. Sehubungan dengan massalah tersebut, dosen hendaknya mempunyai inovasi untuk mengubah cara mengajar dengan menggunakan model pembelajaran yang inovatif.

Beragam model pembelajaran yang dapat digunakan untuk menghasilkan proses belajar mengajar yang lebih berkualitas, tentunya dengan pemilihan model pembelajaran yang tidak sembarangan. Salah satu model pembelajaran yang dapat digunakan untuk dapat meningkatkan hasil belajar mahasiswa pada mata kuliah metode numeric adalah Guided Discovery Learning. Menurut Eggen (Eggen, 2012) model Guided Discovery Learning (temuan terbimbing) adalah satu pendekatan mengajar dimana guru memberi siswa contohcontoh topic spesifik dan memandu siswa untuk memahami topik tersebut. Sedangkan hasil penelitian yang dilakukan oleh Nurkholis (2011) adalah langkah-langkah yang dilakukan dalam pembelajaran dengan metode penemuan terbimbing yaitu merumuskan masalah, menganalisis data, menyusun konjektur, dan membuat kesimpulan.

Berdasarkan hassil penelitian yang dilakukan oleh Istiqomah (Istiqomah, 2014) penerapan Guided Discovery Learning pada pembelajaran matematika di SD N Tulung Balak dapat meningkatkan motivasi dan hasil belajar siswa. Seperti halnya penelitian yang dilakukan oleh Purnomo (Purnomo, 2011), model Guided discovery memberikan dampak yang tidak berbeda, akan tetapi memberikan hasil belajar yang lebih baik dibandingkan dengan model pembelajaran konvensional.

Selain itu penelitian yang dilakukan oleh Putri (Putri, 2009) penerapan model penemuan terbimbing dengan menggunakan Student Worksheet mampu meningkatkan pemahaman konsep matematika siswa kelas VII RSBI di SMPN 1 Bantul. Di tempat lain Rokhayati (Rokhayati, 2010) juga melakukan penelitian dengan judul, "Peningkatan Penguasaan Konsep Matematika Melalui Model Pembelajaran Guided Discovery-Inquiry pada Siswa Kelas VII SMP N 1 Sleman. Berdasarkan penelitian ini diperoleh kesimpulan bahwa penerapan model pembelajaran Guided Discovery-Inquiry dapat meningkatkan penguasaan konsep matematika siswa kelas VII SMP N 1 Sleman

Uddin juga melakukan penelitian dengan judul, "Penerapan Model Guided Discovery Learning Untuk Peningkatan Hasil Belajar Matematika Materi Sifat-Sifat Bangun Ruang Siswa Kelas V Sd 2 Honggosoco". Hasil penelitiannya adalah penerapan model Guided Discovery Learning dapat meningkatkan hasil belajar matematika siswa SD 2 Honggosoco. Diharapkan model Guided Discovery Learning berbassis ketrampilan proses dapat meningkatkan hasil belajar mahasiswa pada mata kuliah metode numeric. Model Guided Discovery Learning berbasis ketrampilan ini sesuai sebab dalam proses pembelajarannya dosen ditempatkan sebagai fasilitator dengan menciptakan proses belajar aktif, kreatif, dan menyenangkan. 
Berdasarkan paparan di atas maka peneliti meruumusan masalah dalam penelitian ini adalah sebagai berikut. Bagaimanakah pembelajaran metode numerik dengan penerapan model Guided Discovery Learning berbasis kemampuan proses? Apakah model Guided Discovery Learnig berbasis kemampuan proses dapat meningkatkan hasil belajar mahasiswa pada mata kuliah metode numerik.

\section{METODE}

Penelitian ini dilaksanakan di IKIP PGRI Bojonegoro yang bertempat di jalan panglima polim 46 Bojonegoro. Penelitian ini dilakukan pada mahasiswa semester 6 yang berjumlah 40 mahasiswa. Penelitian ini dilaksanakan pada semester genap tahun ajaran 2015/2016. Tepatnya bulan Maret sampai dengan Agustus 2016. Instrumen yang digunakan dalam penelitian ini adalah soal tes dan lembar observasi. Soal tes berisi mengenahi pemahan konsep terhadap mata kuliah metode numerik pada sub bab metode mencari akar. Setiap tes kemampuan berisi tiga soal untuk siklus pertama dan tiga soal pula untuk siklus kedua. Sedangkan lembar observasi yang digunakan dalam penelitian ini adalah lembar observasi untuk melihat keterlaksanaan pembelajaran. Lembar observasi digunakan untuk memonitor dan mengevaluasi setiap kegiatan pembelajaran yang dilakukan.

Jenis penelitian ini adalah penelitian tindakan kelas. Setiap siklus terdiri dari empat tahapan yaitu, perencanaan tindakan, pelaksanaan tindakan, observasi/ evaluasi, dan refleksi. ( Kemmis dan Mc Taggart, 1998). Pada tahap perencanaan tindakan, peneliti merencanakan seluruh aktivitas kelas yang akan dilaksanakan seperti membuat rencana pelaksanaan pembelajaran dengan memasukkan sintaks model Guided Discovery Learning berbasis kemampuan proses seperti yang sudah dijelaskan pada bab dua, mempersiapkan diri untuk memandu proses pembelajaran sesuai sintaks, dan menyiapkan instrumen penlitian berupa soal-soal pemecahan metode numerilk. Kemudian tahap kedua yaitu pelaksanaan tindakan, peneliti melaksanakan tindakan sesuai dengan rencana yang sudah dibuat, yaitu menerapkan pembelajaran dengan model Guided Discovery Learning berbasis kemampuan proses. Sedangkan pada tahap ketiga yaitu peneliti melakukan observasi dan evaluasi atas apa yang sudah dilaksanakan pada tahap perencanaan maupun tindakan. Observasi ini dilakukan oleh observer yang kemudian memberikan masukan kepada peneliti untuk mengevaluasi tindakan yang sudah dilaksanakan. Pada tahap terakhir adalah refleksi, peneliti melakukan perefleksian atas tindakan yang dilakukan dengan memberikan soal kepada mahasiswa, jika hasil yang didapat sudah sesuai target, maka penelitian dihentikan, akan tetapi jika hasil tidak sesuai target, maka penelitian akan dilanjutkan pada siklus dua dengan tahapan yang sama pada siklus satu, dengan memperhatikan hasil evaluasi dan refleksi pada siklus satu.

Teknik yang digunakan untuk mengumpulkan data pada penelitian ini adalah observasi dan tes. Data yang dikumpulkan dalam penelitian ini berupa (1) hasil observasi selama proses pembelajaran yang berpedoman pada lembar observasi, (2) hasil tes yang dilaksanakan pada akhir siklus, (3) dokumentasi berupa foto-foto aktifitas dosen dan mahasiswa selama proses pembelajaran berlangsung. Perangkat pembelajaran yang digunakan adalah RPP dan Lembar kerja untuk mahasiswa. 
Penelitian ini terdiri dari dua siklus, dimana setiap siklusnya ada beberapa tahapan, diantaranya: perencanaan, tindakan, observasi, dan refleksi, untuk lebih jelasnya adalah sebagai berikut:

a. Siklus I

1. Perencanaan, pada tahap ini peneliti menyusun RPP sesuai dengan materi yang akan diajarkan dengan menggunakan sintaks dari model Guided Discovery Learning berbasis kemampuan proses. Selain itu, peneliti juga mempersiapkan lembar kerja siswa siklus I dan soal tes untuk siklus I. Peneliti juga mempersiapkan lembar observasi untuk memonitor kegiatan pembelajaran.

2. Pelaksanaan Tindakan, pada tahap ini dosen melaksanakan pembelajaran sesuai dengan RPP yang telah dibuat. Sementara itu, peneliti lain bertugas mengamati aktivitas pembelajaran dengan seksama. Pada siklus I tindakan yang dilakukan yaitu: a). dosen menyampaikan kasus sesuai dengan materi yang diajarkan. b). dosen melakukan tanya jawab dengan mahasiswa. c). mahasiswa memulai kegiatan dengan mencari kasus untuk menemukan konsep. d). dosen membagi mahasiswa menjadi 7-8 kelompok. e). mahasiswa berdiskusi dengan kelompoknya untuk menemukan konsep dengan bimbingan dosen.

3. Observasi, pada tahap ini pengamat lain terus mengamati jalannya pembelajaran, baik aktivitas yang dilakukan oleh dosen maupun mahasiswa. Pengamat lain berada di tempat yang sama dengan dosen dan mencatat segala hal yang terjadi di kelas, baik itu situasi pembelajaran, hasil tindakan, maupun kendala-kendalanya. Hal ini dilakukan untuk mengetahui kesesuaian tindakan dengan rencana tindakan yang telah disusun dan untuk mengetahui seberapa jauh pelaksanaan tindakan berlangsung sesuai dengan harapan dan diharapkan dapat menghasilkan perubahan yang diinginkan.

4. Refleksi, pada tahap ini observasi yang telah dilaksanakan dianalisis untuk mengetahui masalah yang muncul, kekurangan-kekurangan, dan segala hal yang berkaitan dengan tindakan yang telah dilakukan. Kemudian refleksi ini bertujuan untuk mengevaluasi proses yang terjadi dan melihat ketercapaian pembelajaran untuk menyimpulkan data dan informasi yang berhasil dikumpulkan sebagai bahan pertimbangan perencanaan pada siklus berikutnya. Pelaksanaan refleksi berupa diskusi antara dosen yang bersangkutan dengan pengamat lain.

\section{b. Siklus II}

Kegiatan yang dilaksanakan pada siklus II dilakukan sebagai upaya perbaikan dari siklus I. Tahap kerja pada siklus II mengikuti tahap kerja pada siklus I, yaitu diawali dengan perencanaan (perbaikan atas hasil refleksi pada siklus I), tindakan, observasi, dan refleksi. Pada penelitian ini berhenti hingga siklus II, karena hasil penelitian pada siklus II sudah sesuai dengan yang diharapkan.mData hasil observasi yang dilakukan dianalisis dengan memberikan skor untuk penentuan kategori. Persentase keberhasilan $=\frac{\Sigma \text { deskriptor yang muncul }}{\Sigma \text { deskriptor maksimal }}$ x $100 \%$. Hasil perhitungan persentase keberhasilan tindakan pada masing-masing tahapan 
pembelajaran yang diperoleh akan dibandingkan dengan penentuan skor klasifikasi pada tabel berikut ini.

Tabel 3.1. Penentuan Skor Klasifikasi Observasi

\begin{tabular}{cc}
\hline Persentase Keberhasilan Tindakan & Taraf Keberhasilan \\
\hline $85 \%-100 \%$ & Sangat Baik \\
$70 \%-84 \%$ & Baik \\
$65 \%-69 \%$ & Cukup \\
$50 \%-64 \%$ & Kurang \\
$0 \%-49 \%$ & Sangat Kurang \\
\hline
\end{tabular}

Data hasil tes siswa dianalisis dengan membandingkan persentase ketuntasan belajar secara klasikal pada penerapan model Guided Discovery Learning berbasis kemampuan proses pada siklus I dan siklus II. Sedangkan persentase ketuntasan belajar secara klasikal dihitung dengan cara membandingkan jumlah siswa yang mencapai ketuntasan belajar dengan jumlah siswa secara keseluruhan (siswa maksimal) kemudian dikalikan $100 \%$. Persentase ketuntasan belajar klasikal $=\frac{\text { Esiswa yang tuntas }}{\sum \text { jumlah siswa keseluruhan }} \times 100 \%$. Tindakan berhasil jika persentase ketuntasan belajar klasikal mencapai kategori baik dan dengan nilai rata-rata minimal 75.

\section{Tabel 3.2. Penentuan Persentase Ketuntasan Belajar Klasikal}

\begin{tabular}{cc}
\hline Persentase Keberhasilan Tindakan & Taraf Keberhasilan \\
\hline $85 \%-100 \%$ & Sangat Baik \\
$70 \%-84 \%$ & Baik \\
$65 \%-69 \%$ & Cukup \\
$50 \%-64 \%$ & Kurang
\end{tabular}

$0 \%-49 \%$ Sangat Kurang

Data hasil dokumentasi yang diperoleh berupa foto-foto selama kegiatan pembelajaran berlangsung. Dokumentasi foto ini digunakan sebagai gambaran konkret aktivitas-aktivitas pembelajaran yang terjadi di dalam kelas.

\section{HASIL}

(1). Keterlaksanaan Penelitian dengan Model Guided Discovery Learning Berbasis Kemampuan Proses.

Penerapan pembelajaran dengan model Guided Discovery Learning Berbasis Kemampuan Proses sudah dilaksanakan secara optimal. Hal ini ditunjukkan dengan adanya peningkatan hasil persentase keberhasilan tindakan. Dari siklus I dengan persentase keberhasilan tindakan kategori cukup baik meningkat menjadi kategori baik pada siklus II. Peningkatan-peningkatan tersebut terlihat dari hal-hal sebagai berikut.

Pada siklus I tahap perumusan masalah dosen masih sangat dominan dalam pembelajaran, sedangkan pada siklus II dosen sudah mengoptimalkan perannya sebagai fasilitator. Tahap pengumpulan data pada siklus I beberapa mahasiswa belum paham dengan apa yang akan dilakukan, sehingga dosen sangat dominan dalam pembelajaran. Akan tetapi pada siklus II mahasiswa sudah paham dengan apa yang harus dilakukan dan sangat antusias 
dalam mendiskusikan pokok bahasan yang dipelajari. Dari hal ini terlihat peran dosen sudah tidak dominan dalam pembelajaran. Pada tahap pengujian jawaban sementara di siklus I hanya ada beberapa mahasiswa yang ikut membahas. Hal ini sangat jauh berbeda dengan siklus II, dimana mahasiswa sangat antusias dalam melaksanakan diskusi kecil dengan kelompoknya untuk menguji jawaban sementara yang sudah direncanakan sebelumnya. Di tahap pemberian kesimpulan pada siklus I beberapa mahasiswa masih kurang tepat dalam menyampaikan pendapatnya. Sedangkan pada siklus II sudah banyak mahasiswa yang tepat dalam memberikan kesimpulan.

\section{(2). Hasil Tes Prestasi Belajar Mahasiswa.}

Hasil tes prestasi belajar pada siklus I menunjukkan bahwa persentase ketuntasan belajar klasikal mencapai kategori cukup baik yaitu mencapai 30\%, akan tetapi nilai rata-rata kurang dari 75. Hal ini belum memenuhi indikator keberhasilan, karena tindakan berhasil jika persentase ketuntasan belajar klasikal mencapai kategori cukup baik dan dengan nilai ratarata minimal 75. Sedangkan rata-rata kelas baru mencapai 70. Dari hal ini maka perlu dilakukan tindakan pada siklus II. Sedangkan hasil tes prestasi belajar pada siklus II menunjukkan bahwa persentase ketuntasan belajar klasikal mencapai kategori baik dan nilai rata-rata lebih dari 75 . Hal ini sudah memenuhi indikator keberhasilan, karena tindakan pada siklus II ini sudah berhasil maka tidak perlu dilakukan tindakan pada siklus selanjutnya. Dari hal ini menunjukkan bahwa terjadi peningkatkan hasil belajar mahasiswa pada mata kuliah metode numerik melalui model Guided Discovery Learning berbasis kemampuan proses.

\section{PEMBAHASAN}

a). Keterlaksanaan Penelitian dengan Model Guided Discovery Learning Berbasis Kemampuan Proses.

Berdasarkan deskripsi hasil penelitian di atas, terlihat bahwa keterlaksanaan penelitian dengan Model Guided Discovery Learning Berbasis Kemampuan Proses telah berjalan dengan baik. Hal ini dapat ditunjukkan oleh data hasil observasi pada siklus I dan siklus II. Ada perubahan pembelajaran yang lebih baik antara keterlaksanaan pembelajaran pada siklus I dengan keterlaksanaan pembelajaran pada siklus II.

Perubahan-perubahan tersebut diantaranya adalah pada siklus I maupun siklus II di tahap orientasi, dosen sudah mengkondisikan mahasiswa untuk fokus dan memahami pokok bahasan yang dikaji. Sedangkan pada tahap perumusan masalah, dosen telah mengoptimalkan pembelajaran dengan model Guided Discovery Learning Berbasis Kemampuan Proses, hal inipun sudah terlaksana pada siklus I maupun siklus II. Sedangkan pada tahap menemukan jawaban sementara, dosen meminta mahasiswa untuk menemukan sendiri jawaban tersebut berdasarkan pendapat masing-masing dan dengan diskusi kelompok. pada siklus II mahasiswa tampak sudah mampu memberikan jawaban sementara cukup baik, selain itu juga mampu menemukan sendiri jawaban sementara dari persoalan yang telah diberikan oleh dosen. Sedangkan pada siklus I, masih banyak mahasiswa yang belum mampu menemukan 
jawaban sementara, selain itu diskusi keloompok juga belum berjalan dengan baik. Pada tahap mengumpulkan data, dosen mengarahkan mahasiswa untuk mengumpulkan data yang relevan dengan pokok bahasan yang sedang dikaji sesuai dengan langkah-langkah pada LKS.

Pada siklus II mahasiswa sudah melaksanakan tahap ini dengan baik. Mahasiswa antusias berdiskusi dengan kelompoknya masing-masing untuk mengumpulkan data yang relevan sehingga mampu menyimpulkan dengan benar. Sedangkan pada siklus I, mahasiswa belum mampu mengumpulkan data, dan dosen sangat dominan dalam pembelajaran. Pada tahap pengujian jawaban sementara yang telah ditentukan sebelumnya, pada siklus II hampir seluruh mahasiswa melaksanakan tahap ini dengan baik, terjadi diskusi kecil antar kelompok, sedangkan pada siklus I belum terjadi diskusi kecil antar mahasiswa. Pada tahap kesimpulan, mahasiswa sudah menyimpulkan dan dosen memberikan penegasan ulang mengenai kesimpulan tersebut. Pada siklus II mahasiswa sudah menyimpulkan dengan baik dan benar, sedangkan pada siklus I mahasiswa kurang tepat dalam memberikan kesimpulan.

b). Hasil Tes Prestasi Belajar Mahasiswa.

Di akhir setiap siklus, dosen memberikan soal tes kepada mahasiswa. Hasil tes prestasi belajar pada siklus I menunjukkan bahwa persentase ketuntasan belajar klasikal mencapai kategori cukup baik yaitu mencapai 30\%, akan tetapi nilai rata-rata kurang dari 75 . Hal ini belum memenuhi indikator keberhasilan, karena tindakan berhasil jika persentase ketuntasan belajar klasikal mencapai kategori cukup baik dan dengan nilai rata-rata minimal 75. Sedangkan rata-rata kelas baru mencapai 70. Dari hal ini maka perlu dilakukan tindakan pada siklus II.

Sedangkan hasil tes prestasi belajar pada siklus II menunjukkan bahwa persentase ketuntasan belajar klasikal mencapai kategori baik dan nilai rata-rata lebih dari 75 . Hal ini sudah memenuhi indikator keberhasilan, karena tindakan pada siklus II ini sudah berhasil maka tidak perlu dilakukan tindakan pada siklus selanjutnya. Dari hal ini menunjukkan bahwa terjadi peningkatkan hasil belajar mahasiswa pada mata kuliah metode numerik melalui model Guided Discovery Learning berbasis kemampuan proses.

\section{SIMPULAN DAN SARAN}

\section{Simpulan}

(1). Keterlaksanaan Penelitian dengan Model Guided Discovery Learning Berbasis Kemampuan Proses.

Berdasarkan deskripsi hasil penelitian di atas, terlihat bahwa keterlaksanaan penelitian dengan Model Guided Discovery Learning Berbasis Kemampuan Proses telah berjalan dengan baik. Hal ini dapat ditunjukkan oleh data hasil observasi pada siklus I dan siklus II. Ada perubahan pembelajaran yang lebih baik antara keterlaksanaan pembelajaran pada siklus I dengan keterlaksanaan pembelajaran pada siklus II.

Perubahan-perubahan tersebut diantaranya adalah pada siklus I maupun siklus II di tahap orientasi, dosen sudah mengkondisikan mahasiswa untuk fokus dan memahami pokok bahasan yang dikaji. Sedangkan pada tahap perumusan masalah, dosen telah mengoptimalkan pembelajaran dengan model Guided Discovery Learning Berbasis Kemampuan Proses, hal 
inipun sudah terlaksana pada siklus I maupun siklus II. Sedangkan pada tahap menemukan jawaban sementara, dosen meminta mahasiswa untuk menemukan sendiri jawaban tersebut berdasarkan pendapat masing-masing dan dengan diskusi kelompok. pada siklus II mahasiswa tampak sudah mampu memberikan jawaban sementara cukup baik, selain itu juga mampu menemukan sendiri jawaban sementara dari persoalan yang telah diberikan oleh dosen. Sedangkan pada siklus I, masih banyak mahasiswa yang belum mampu menemukan jawaban sementara, selain itu diskusi keloompok juga belum berjalan dengan baik. Pada tahap mengumpulkan data, dosen mengarahkan mahasiswa untuk mengumpulkan data yang relevan dengan pokok bahasan yang sedang dikaji sesuai dengan langkah-langkah pada LKS. Pada siklus II mahasiswa sudah melaksanakan tahap ini dengan baik. Mahasiswa antusias berdiskusi dengan kelompoknya masing-masing untuk mengumpulkan data yang relevan sehingga mampu menyimpulkan dengan benar. Sedangkan pada siklus I, mahasiswa belum mampu mengumpulkan data, dan dosen sangat dominan dalam pembelajaran. Pada tahap pengujian jawaban sementara yang telah ditentukan sebelumnya, pada siklus II hampir seluruh mahasiswa melaksanakan tahap ini dengan baik, terjadi diskusi kecil antar kelompok, sedangkan pada siklus I belum terjadi diskusi kecil antar mahasiswa. Pada tahap kesimpulan, mahasiswa sudah menyimpulkan dan dosen memberikan penegasan ulang mengenai kesimpulan tersebut. Pada siklus II mahasiswa sudah menyimpulkan dengan baik dan benar, sedangkan pada siklus I mahasiswa kurang tepat dalam memberikan kesimpulan.

(2). Hasil Tes Prestasi Belajar Mahasiswa.

Di akhir setiap siklus, dosen memberikan soal tes kepada mahasiswa. Hasil tes prestasi belajar pada siklus I menunjukkan bahwa persentase ketuntasan belajar klasikal mencapai kategori cukup baik yaitu mencapai 30\%, akan tetapi nilai rata-rata kurang dari 75 . Hal ini belum memenuhi indikator keberhasilan, karena tindakan berhasil jika persentase ketuntasan belajar klasikal mencapai kategori cukup baik dan dengan nilai rata-rata minimal 75. Sedangkan rata-rata kelas baru mencapai 70. Dari hal ini maka perlu dilakukan tindakan pada siklus II.

Sedangkan hasil tes prestasi belajar pada siklus II menunjukkan bahwa persentase ketuntasan belajar klasikal mencapai kategori baik dan nilai rata-rata lebih dari 75 . Hal ini sudah memenuhi indikator keberhasilan, karena tindakan pada siklus II ini sudah berhasil maka tidak perlu dilakukan tindakan pada siklus selanjutnya. Dari hal ini menunjukkan bahwa terjadi peningkatkan hasil belajar mahasiswa pada mata kuliah metode numerik melalui model Guided Discovery Learning berbasis kemampuan proses.

\section{Saran}

Pembelajaran metode numerik dengan model Guided Discovery Learning berbasis kemampuan proses dapat meningkatkan hasil belajar mahasiswa semester enam. Sehingga peneliti menyarankan model ini dapat digunakan untuk membelajarkan mata kuliah metode numerik ataupun mata kuliah yang sejenis dengannya. Akan tetapi perlu diperhatikan 
sintaksnya dengan baik. Untuk mengontrol kegiatan diskusi, dosen harus aktif membimbing proses diskusi, agar pembelajaran dapat berjalan dengan baik

\section{DAFTAR RUJUKAN}

Eggen, P and Kauchak, D. 2012. Strategi dan Model Pembelajaran. Jakarta: PT Indeks.

Fatih I, Sarengat, \& Muncarno. 2014. Penerapan Model Guided Discovery Learning untuk Meningkatkan Motivasi dan Hasil Belajar Siswa. Skripsi: Universitas Lampung.

Herman, H. 2003. Pengembangan Kurikulum dan Pembelajaran Matematika. Malang: JICA -Universitas Negeri Malang.

Markaban. 2006. Model Pembelajaran Matematika dengan Pendekatan Penemuan Terbimbing. Yogyakarta: Departemen pendidikan nasional pusat pengembangan dan penataran guru matematika.

Misriyadi. 2013. Upaya Meningkatkan Aktivitas dan Prestasi Belajar melalui Model Pembelajaran Penemuan Terbimbing pada Mata Pelajaran Matematika di Kelas IV SDN 3 Kresno Widodo Kabupaten Pesawaran Tahun Pelajaran 2012/2013. Skripsi: Universitas Lampung.

Uddin, M. R. 2014. Penerapan Model Guided Discovery Learning Dapat Meningkatkan Hasil Belajar Matematika Siswa SD 2 Honggosoco. Skripsi: Universitas Muria Kudus.

Nurcholis. 2013. Implementasi Metode Penemuan Terbimbing Untuk Meningkatkan Hasil Belajar Siswa pada Penarikan Kesimpulan Logika Matematika. Jurnal Elektronik Pendidikan Matematika Tadulako, 01, 32-42.

Nupita, Evi. 2013. Penerapan Model Pembelajaran Penemuan Terbimbing untuk meningkatkan Hasil Belajar dan Keterampilan Pemecahan Masalah pada Siswa Kelas $V$ SD. Skripsi: Unesa.

Munir, R. 2003. Metode Numerik. Bandung: Informatika.

Ranggi S. M. Pi. 2009. Upaya Meningkatkan Pemahaman Konsep Matematika Siswa Kelas VII RSBI dan SMPN 1 Bantul melalui Penemuan Terbimbing dengan Menggunakan Student Worksheet. Skripsi: Universitas Negeri Yogyakarta.

Rokhayati, N. 2010. Peningkatan Penguasaan Konsep Matematika melalui Model Pembelajaran Guided Discovery-Inquiry pada Siswa Kelas VII SMP N 1 Sleman. Skripsi: Universitas Negeri Yogyakarta.

Simamora, I. 2010. Metode Penemuan Terbimbing.Jakarta: PT Indeks.

Sudirman, N. Et al. 1992. Ilmu Pendidikan. Bandung: PT. Remaja Rosdakarya.

Suryosubroto, B. 2009. Proses Belajar Mengajar di Sekolah. Jakarta: Rineka Cipta.

Syarif. 2012. Pembelajaran Matematika dengan Model Penemuan Terbimbing.Jakarta: Rineka cipta.

UUD 1945 Pasal 31 ayat 3 tentang Pendidikan. Jakarta: Mendikbud.

Yoppy Wahyu Purnomo. 2011. Keefektifan Model Penemuan Terbimbing Dan Cooperative Learning Pada Pembelajaran Matematika. Jurnal Kependidikan, 41, 23-33.

Zuhelmi. 2009. Penilaian Psikomotor dan Respon Siswa dalam Pembelajaran Sains Fisika melalui Penerapan Penemuan Terbimbing. (online), vol 3 (2), 5 halaman. Tersedia: http:// ejournal.unri.ac.id/index.php/JGS/Article/download/300/29p. 